\title{
Pengaruh Simvastatin Terhadap Kadar Proliferasi Limfosit Mencit Balb/C Yang Diinduced Sepsis Dengan LPS
}

\section{The Effect Of Simvastatin On Lymphocyte Proliferation Level In Lypopolisaccharide Sepsis Induced Of Balb/C Mice}

\author{
Made Ryan Kharmayani $\bigotimes_{*}^{*}$, Haris Lutfi*, Danu Soesilowati* \\ *Bagian Anestesiologi dan Terapi Intensif FK Undip/ RSUP dr. Kariadi, Semarang \\ $\triangle$ Korespondensi/correspondence: ryan_giri@yahoo.com
}

\begin{abstract}
Background: Statins, inhibitors of 3-hydroxy-3-methylglutaryl coenzyme A (HMGCoA) reductase is an effective agent in lowering lipids. Statins also modify intercellular interactions and cellular chemotaxis and potentially affect the immune system by inhibiting $T$ lymphocyte interactions between cellular adhesion molecule LFA-1, ICAM-1 and IFN-r which play a role in the expression of MHC II on APC and an important process in T cell activation. Inhibition of MHC II expression resulted in inhibition of CD4 lymphocyte activation, resulting in decreased differentiation of Th1 and proinflamatory cytokines.
\end{abstract}

Objective: To determine dose-effect relationship of lymphocyte proliferation level in balb/c mice induced by intraperitoneal lipopolysaccharide after administration of simvastatin.

Methods: A randomized post test only controlled group laboratoric experimental studied in $20 \mathrm{Balb} / \mathrm{c}$ mice divided into 4 group and injected intraperitoneally with lipopolysaccharide $10 \mathrm{mg} / \mathrm{BW}$ and 0,03 $\mathrm{mg}$ doses of simvastatin; 0,06 $\mathrm{mg}$ and 0,12 $\mathrm{mg}$ orally. The controle group KI, K2 which received 0,03 $\mathrm{mg}$ simvaststin, $K 3$ received $0,006 \mathrm{mg}$ simvaststin, and $\mathrm{K} 4$ which received 0,12 $\mathrm{mg}$ of simvastatin. Examination of cultured spleen lymphocyte taken after 72 hours of administration of simvastatin. Parametric ANOVA is used as a statistical test followed by a posteriori test.

Result: Mean levels of lymphocytes in the KI group $(1.546+0.106)$, K2 $(0.541+$ $0.046), K 3(0.471+0.013)$ and $K 4(0.02+0.553)$. There were significant decreased in lymphocyte levels in the K2,K3 and $K 4$ groups compared to $K 1(p<0.05)$. There were no significant differences between $K 2, K 3$ and $K 4$ groups $(p>0.05)$ but found significant differences between groups $K 3$ to $K 4$ ( $p<0.05$ ).

Conclusion: Simvastatin significantly decreased the levels of lymphocyte proliferation in mice that received intraperitoneal injection of LPS compared with mice that did not receive simvastatin. $0.06 \mathrm{mg}$ dose of simvastatin had the greatest effect to suppress levels of lymphocyte proliferation.

Keywords: lipopolysaccharide, simvastatin, lymphocyte proliferation 


\section{ABSTRAK}

Latar Belakang: Statin, inhibitor 3-hidroxy-3-methylglutaryl coenzyme A (HMG-CoA) reductase merupakan agen yang paling efektif dalam menurunkan lipid dan mempunyai efek pleiotrofik yaitu anti inflamatori dan immunomodulatori. Statin juga memodifikasi interaksi interseluler dan kemotaksis seluler pada sistem imun serta berpotensi mempengaruhi limfosit $T$ dengan cara menghambat iinteraksi antara adhesi molekul seluler leukocyte function-associated antigen-1 (LFA-1) dan intercellular adhesion molecule-1 (ICAM-1), juga menurunkan interferon gamma (IFN - y) yang berperan dalam ekspresi class II major histocompatibilty complex (MHC II) pada antigen precenting cells (APC) dan merupakan proses penting dalam aktivasi sel T. Penurunan ekspresi MHC II berakibat pada inhibisi aktivasi CD 4 limfosit, sehingga mengakibatkan penurunan diferensiasi T helper-1 (Th1) dan pelepasan sitokin proinflamasi juga menurun.

Tujuan: Membuktikan efek simvastatin dosis bertingkat peroral pada mencit yang diberi LPS intraperitoneal terhadap penurunan kadar proliferasi limfosit.

Metode: Penelitian eksperimental laboratorik dengan desain randomized post test only controlled group pada 20 ekor mencit Balb/c yang disuntik lipopolisakarida 10 $\mathrm{mg} / \mathrm{KgBB}$ intraperitoneal dan simvastatin dosis 0,03 $\mathrm{mg}, 0,06 \mathrm{mg}$ dan 0,12 $\mathrm{mg}$ peroral. Mencit dibagi menjadi 4 kelompok secara random, yaitu K1 sebagai kontrol, $\mathrm{K} 2$ yang mendapat simvastatin 0,03 $\mathrm{mg}$, K3 yang mendapat simvastatin 0,06 $\mathrm{mg}$ dan $K 4$ yang mendapat simvastatin 0,12 mg. Pemeriksaan limfosit diambil dari kultur limpa setelah 72 jam pemberian simvastatin. Uji statistik yang digunakan adalah parametrik ANOVA dan dilanjutkan Posteriori

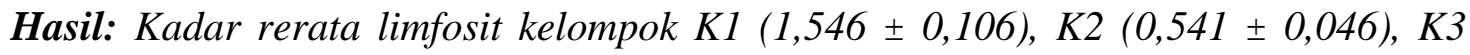
$(0,471 \pm 0,013)$ dan $K 4(0,553 \pm 0,02)$. Terdapat penurunan kadar limfosit secara signifikan pada kelompok K2, K3 dan K4 dibanding K1 dengan $p<0,05$. Tidak terdapat perbedaan bermakna antara kadar limfosit kelompok $K 2$ dengan kelompok $K 3$ dan $K 4(p>0,05)$ tetapi didapatkan perbedaan bermakna antara kelompok $K 3$ dibandingkan kelompok $K 4$ ( $p<0,05)$.

Simpulan: Simvastatin secara signifikan menurunkan kadar proliferasi limfosit pada mencit yang diberi LPS intraperitoneal. Dosis 0,06 mg memiliki efek menekan kadar proliferasi limfosit paling besar.

Kata kunci: simvastatin, lipopolisakarida, proliferasi limfosit

\section{PENDAHULUAN}

Sepsis dan syok sepsis merupakan penyebab kematian dengan tingkat mortalitas yang tinggi. ${ }^{1}$ Di Amerika, sepsis dan syok sepsis menduduki tempat ke 10 sebagai penyebab utama kematian, diperkirakan 400.000 sampai 500.000 kasus sepsis terjadi setiap tahunnya dan hanya 55\% - 65\% dari pasien sepsis yang mampu bertahan 
hidup. ${ }^{2}$ Severe sepsis dan syok sepsis menyebabkan kematian 1 dari 4 orang (bahkan lebih) dan meningkatkan insiden sebanyak $1-5 \%$. Sama seperti multiple trauma, acute myocardial infarct atau stroke, penanganan yang cepat dan pemilihan terapi yang tepat setelah diagnosis severe sepsis ditegakkan akan mempengaruhi outcome. $^{3}$

Selama beberapa dekade terakhir ini, para peneliti berupaya membuat berbagai strategi terapetik, tetapi masih gagal dalam menurunkan tingkat mortalitas pada pasien severe sepsis. Strategi terapetik dimasa depan dikembangkan berdasarkan pemahaman terhadap patofisiologi sepsis. Sepsis mengacu kepada systemic inflammatory response syndrome (SIRS) yang memperlihatkan respon inflamasi dan cytokine storm. ${ }^{4}$

Sekitar $60 \%-70 \%$ sepsis disebabkan bakteri gram negatif. Substansi bakteri gram negatif yang disebut lipopolysaccharide (LPS) merupakan faktor patogenik sepsis yang terletak pada membran terluar bakteri. 5,6 Substansi bakteri tersebut kemudian akan bereaksi dengan reseptor spesifik sehingga akan memacu terjadinya cascade inflamasi. ${ }^{7}$

Di dalam organ limfoid perifer, sel khusus seperti makrofag mempresentasikan antigen pada limfosit. Sel limfosit $\mathrm{T}$ naiff yang berikatan dengan antigen akan berproliferasi dan berdiferensiasi menjadi sel efektor spesifik antigen, sedangkan sel limfosit B berproliferasi dan berdiferensiasi menjadi sel pensekresi antibodi. ${ }^{8}$

Golongan statin adalah obat yang efektif dan ditoleransi dengan baik untuk mengobati dislipidemia. ${ }^{9,10}$ Statin juga dikenal sebagai obat yang merupakan inhibitor kuat pada proses inflamasi. ${ }^{9,11}$ Mekanisme statin dalam menyebabkan modulasi respon imun merupakan hal yang kompleks, akan tetapi dikatakan tidak berkaitan dengan efeknya dalam menurunkan kolesterol LDL. ${ }^{7,9,11}$

Almog Y dkk menemukan pemberian statin menurunkan risiko terjadinya severe sepsis pada pasien sepsis dan risiko mortalitas akibat infeksi pada pasien dengan atherosclerosis di ICU. ${ }^{1,12}$ Merx MW dkk melaporkan atorvastatin, simvastatin, pravastatin $(0,2 \mathrm{ug} / \mathrm{g})$ secara signifikan meningkatkan survival rate (daya tahan hidup) mencit dengan sepsis serta melaporkan simvastatin $(0,2 \mathrm{ug} / \mathrm{g})$ secara signifikan menjaga kestabilan hemodinamik dan cardiac output mencit dengan sepsis dalam 20 jam. ${ }^{13,14}$ Zelvyte I dkk melaporkan pravastatin $50 \mathrm{ug} / \mathrm{ml}$ secara signifikan mensupresi kadar NF$\mathrm{kB}$ pada monosit manusia in vitro. ${ }^{15}$ Yasuda $\mathrm{H}$ dkk melaporkan simvastatin $40 \mathrm{mg} / \mathrm{kgBB}$ secara signifikan menurunkan jumlah TNF- $\alpha$ mencit dengan sepsis. ${ }^{16}$ Arnaud C dkk melaporkan pravastatin 5 , 10, dan 20 $\mu \mathrm{mol} / \mathrm{L}, \quad$ simvastatin $0,01,0,1$, dan 1 $\mu \mathrm{mol} / \mathrm{L}$, atorvastatin $0,01,0,1$, dan 1 $\mu \mathrm{mol} / \mathrm{L}$ secara signifikan menurunkan IL -6 dari hepatosit manusia in vitro. ${ }^{17}$ 
Penelitian tentang efek statin terhadap kadar proliferasi limfosit belum banyak dilakukan. Statin dalam terapi mempunyai beberapa dosis bertingkat. Penelitian ini dilakukan untuk mengetahui pengaruh pemberian simvastatin terhadap kadar proliferasi limfosit pada mencit, dengan menggunakan dosis bertingkat yaitu 10 $\mathrm{mg}, 20 \mathrm{mg}$ dan $40 \mathrm{mg}$ pada manusia, yang kemudian dikonversikan ke dalam dosis mencit dengan berat badan $20 \mathrm{~g}$ menjadi $0,03 \mathrm{mg}, 0,06 \mathrm{mg}$ dan $0,12 \mathrm{mg}$ setelah pemberian LPS.

\section{METODE}

Penelitian ini termasuk eksperimental laboratorik dengan desain post test only controlled group dengan tujuan mencari pengaruh pemberian simvastatin peroral pada mencit yang diberi lipopolisakarida intraperitoneal terhadap kadar proliferasi limfosit. Sampel penelitian 20 ekor mencit balb/c jantan, umur $8-10$ minggu, berat $20-30$ gram, sehat dan tidak tampak cacat secara anatomi.

Mencit yang kami inklusikan dalam penelitian ini adalah Mencit Balb/c jantan berumur 8-10 minggu dengan berat badan 20 - 30 gram, tidak ada kelainan anatomis, dan aktif selama masa adaptasi. Mencit kami eksklusikan bila sakit selama masa adaptasi 7 hari atau gerakan tidak aktif.

Besar sampel sebanyak 20 mencit berdasakan Research Guidelines For Evalution The safety and Efficiacy of Herbal Medicines dari WHO. Mencit dibagi dalam 4 kelompok perlakuan, sehingga jumlah sampel 5 ekor perkelompok. Sampel yang memenuhi kriteria inklusi diadaptasikan dengan dikandangkan per kelompok dan diberi pakan standar serta minum yang sama selama 1 minggu secara ad libitum.

Kelompok dibagi menjadi 4 yaitu kelompok kontrol (K1), Perlakuan 1 (K2), Perlakuan 2 (K3), Perlakuan 3 (K4). Mencit kelompok kontrol (K1) disuntik LPS intraperitoneal $10 \mathrm{mg} /$ $\mathrm{KgBB}$ dan mendapat $\mathrm{NaCl} 0,9 \%$ peroral.: Mencit kelompok perlakuan 1 (K2) disuntik LPS intraperitoneal $10 \mathrm{mg} / \mathrm{KgBB}$ dan mendapat simvastatin $0,03 \mathrm{mg}$ peroral. Mencit kelompok perlakuan 2 (K3) disuntik LPS intraperitoneal $10 \mathrm{mg} /$ KgBB dan mendapat simvastatin 0,06 mg peroral. Mencit kelompok perlakuan 3 (K4) disuntik LPS intraperitoneal 10 $\mathrm{mg} / \mathrm{KgBB}$ dan mendapat simvastatin $0,12 \mathrm{mg}$ peroral.

Dosis obat yang diberikan disetarakan dengan dosis pada manusia dengan berat badan $70 \mathrm{~kg}$ dikalikan konstanta uji terapi pada hewan coba mencit dengan berat badan 20 g yaitu 0,0026 .

Setelah ditunggu selama 6 jam kemudian dilakukan pengambilan dan kultur limfosit limpa. Kultur limfosit limpa dilakukan selama 72 jam untuk selanjutnya dilakukan pengukuran kadar proliferasi limfosit.

\section{HASIL}

Penelitian ini menggunakan 20 ekor 
mencit Balb/c jantan, dari keturunan murni berumur dua setengah bulan dan berat badan 20-30 gram. Penelitian menggunakan 4 kelompok yaitu kelompok kontrol (K1) terdiri dari 5 ekor mencit yang diberikan perlakuan LPS intraperitoneal $10 \mathrm{mg} / \mathrm{kgBB}$. Kelompok perlakuan 1 (K2), kelompok perlakuan 2 (K3) dan kelompok perlakuan 3 (K4) masing-masing terdiri 5 ekor mencit mendapatkan perlakuan LPS intraperitoneal $10 \mathrm{mg} / \mathrm{kgBB}$ dan simvastatin peroral $(0,03 \mathrm{mg}, 0,06 \mathrm{mg}$ dan $0,12 \mathrm{mg}$ ).

Kadar limfosit dari tiap-tiap kelompok perlakuan dihitung dengan menggunakan metode modifikasi Gries dari Green et al dan Ding et al. Kadar limfosit dibaca dengan alat ELISA reader, kemudian hasilnya dihitung menggunakan persamaan regresi linier. Hasil dari pengukuran tersebut dapat dilihat pada tabel 2 .

Rerata hitung limfosit pada kelompok $\mathrm{KI}(1.546 \pm 0.106), \mathrm{K} 2(0.541 \pm 0.046)$, $\mathrm{K} 3(0.471 \pm 0.013)$ dan K4 (0.02 \pm 0.553). Terdapat penurunan yang bermakna pada hitung limfosit pada kelompok K2, K3 dan K4 dibandingkan K1 ( $\mathrm{p}<0.05)$. Tidak terdapat perbedaan bermakna antara kelompok K2, K3 dan K4 ( $>>0.05)$ tetapi tidak ditemukan perbedaan bermakna antara kelompok K3 dan K4 ( $<<0.05)$.

Hasil pengamatan rerata kadar limfosit pada keempat kelompok menunjukkan jumlah yang berbeda yaitu pada kelompok perlakuan 2 (K3) menunjukkan kadar limfosit paling rendah dibandingkan kelompok kontrol (K1).

\section{PEMBAHASAN}

Injeksi LPS pada hewan coba dan manusia dapat menimbulkan efek hemodinamik menyerupai syok sepsis. ${ }^{21}$ Endotoksin menyebabkan host mengeluarkan mediator inflamasi berupa sitokin yang secara tidak langsung dapat menyebabkan sepsis. ${ }^{22}$ LPS di dalam darah akan berikatan dengan protein darah membentuk lipopolysaccharide binding protein (LBP) ${ }^{6,24}$ LBP yang berada dalam darah akan bereaksi dengan makrofag melalui TLRs4 (Toll Like Receptors 4) sebagai reseptor transmembran dengan perantaraan reseptor CD14, sehingga makrofag akan mengaktifkan NF-kB dan melepaskan sitokin proinflamasi. Makrofag akan mengeluarkan TNF, interleukin 1 (IL-1), IL-6 dan IL-8 yang merupakan mediator kunci dan sering meningkat sangat tinggi pada keadaan sepsis. ${ }^{6}$

Mekanisme imun host terdiri dari imunitas innate (natural,native) yang memediasi proteksi inisial melawan infeksi dan imunitas adaptive (spesifik, acquired) yang timbul lebih lambat dan memediasi sistim imun beberapa saat kemudian dan lebih efektif melawan infeksi.

Respon imun innate memberikan sinyal yang hubungannnya dengan antigen berfungsi untuk menstimulasi proliferasi 
Tabel 1. Karakteristik Umum Subyek Penelitian

\begin{tabular}{|c|c|c|c|}
\hline Variabel & HES NS & HES BS & $\mathbf{p}$ \\
\hline Umur & $28,33 \pm 5,015$ & $28,08 \pm 4,907$ & $0,903^{*}$ \\
\hline \multicolumn{4}{|l|}{ ASA } \\
\hline I & $6(25,0 \%)$ & $7(29,2 \%)$ & $0,682 * *$ \\
\hline II & $6(25,0 \%)$ & $5(20,8 \%)$ & \\
\hline BMBMI & $22,12 \pm 1,801$ & $22,48 \pm 1,524$ & $0,604 *$ \\
\hline
\end{tabular}

Tabel 2. Perbedaan pengaruh pemberian HES $6 \%$ (200) dalam larutan berimbang dan HES $6 \%$ (200) dalam $\mathrm{NaCl} 0,9 \%$ terhadap perubahan $\mathrm{BE}$

\begin{tabular}{llll}
\hline Variabel & BE pre & BE post & p \\
\hline HES NS & $-6,59 \pm 1,549$ & $-7,83 \pm 2,086$ & $0,003^{* *}$ \\
HES BS & $-3,26 \pm 0,680$ & $-2,97 \pm 0,597$ & $0,216^{* *}$ \\
\hline $\mathrm{p}$ & $0,000^{*}$ & $0,000^{*}$ & \\
\hline
\end{tabular}

Tabel 3. Perbedaan pengaruh pemberian HES $6 \%$ (200) dalam larutan berimbang dan HES $6 \%$ (200) dalam $\mathrm{NaCl} 0,9 \%$ terhadap perubahan SID

\begin{tabular}{llll}
\hline Variabel & SID pre & SID post & p \\
\hline HES NS & $37,48 \pm 2,368$ & $34,38 \pm 2,758$ & $0,000^{* *}$ \\
HES BS & $37,75 \pm 1,215$ & $38,00 \pm 1,206$ & $0,555^{* *}$ \\
\hline $\mathrm{p}$ & $0,732^{*}$ & $0,000^{*}$ & \\
\hline
\end{tabular}


dan diferensiasi dari limfosit $\mathrm{T}$ yang spesifik terhadap antigen. Imunitas innate berperan sebagai inisiasi sinyal peringatan bagi sistim imun adaptive untuk memberikan respon proteksi terhadap host. Molekul yang diproduksi selama reaksi imun innate yang berfungsi sebagai sinyal kedua untuk aktivasi limfosit yaitu kostimulator, sitokin dan produk komplemen. ${ }^{22}$

Hasil pengamatan dapat dilihat bahwa terdapat penurunan jumlah limfosit yang bermakna pada pemberian simvastatin baik pada dosis $0,03 \mathrm{mg}$, $0,06 \mathrm{mg}$ maupun pada pemberian simvastatin dosis $0,12 \mathrm{mg}$ dibandingkan dengan kelompok yang tidak diberi simvastatin. Dari penelitian yang dilakukan oleh Neuhaus dkk menyatakan bahwa golongan statin menghambat proliferasi dari Peripheral blood mononuclear cells (PBMC) limfosit dalam dose-dependent dimana simvastatin yang paling poten diikuti dengan lovastatin dan mevastatin. Efek statin didapatkan pada dosis 1 sampai $10 \mu \mathrm{M}^{23} \quad$ Sedangkan Hillyard dkk menyatakan bahwa dari penelitian secara in vitro, penambahan simvastatin $\quad 1 \mu \mathrm{M}$ menurunkan proliferasi limfosit sebesar $39 \%{ }^{22}$

Statin, inhibitor 3-hidroxy-3methylglutaryl coenzyme A (HMG-CoA) reductase merupakan agen efektif dalam menurunkan lipid dan dapat memodulasi respon imun. Statin berpotensi mempengaruhi limfosit $\mathrm{T}$ dengan cara menghambat interaksi antara adhesi molekul seluler LFA-1 dan ICAM-1, juga menurunkan IFN- $\gamma$ yang berperan dalam ekspresi MHC II pada APC dan merupakan proses penting dalam aktivasi sel T. Efek statin pada MHC II adalah spesifik untuk ekspresi yang terinduced.. Selain itu dengan menghambat produksi $L$ mevalonic acid dan metabolitnya, statin mencegah pengiriman sinyal dari isoprenilasi molekul Ras dan Rho yang juga ikut mengaktivasi limfosit ${ }^{21,23,24}$

Yasuda dkk menyatakan bahwa simvastatin menekan TNF- $\alpha$ mencit sepsis. Pada penelitian lain Arnaud dan Chello menyatakan bahwa simvastatain menekan IL-6 dan IL-8. TNF- $\alpha$ merupakan sitokin pertama yang terinduksi setelah stimulasi LPS yang kemudian juga akan menstimulasi IL-1 dan IL-6 pada makrofag, monosit, neutrofil dan sel endotel. Efek supresi simvastatin terhadap IL-6 dan IL-8 dapat secara langsung maupun melalui penghambatan pelepasan TNF- $\alpha$ yang diinduksi oleh LPS. ${ }^{21,22}$

Nie dkk menyatakan bahwa dari penelitian secara in vitro, proliferasi limfosit dihambat oleh statin dalam dose -dependent, lebih jauh disebutkan bahwa pemberian statin memperlihatkan efek inhibisi pada CD3/CD28 yang memediasi aktivasi dan proliferasi sel $\mathrm{T}$. Selain itu statin secara signifikan mempengaruhi ekspresi mRNA dan menghambat produksi sitokin IL-2 dan IFN-@c. ${ }^{25}$ Hillyard dkk menyatakan bahwa pemberian statin (fluvastatin) $10 \mu \mathrm{M} / \mathrm{L}$ menyebabkan inhibisi proliferasi sel $\mathrm{T}$ yang berkaitan dengan 
respon CD3 secara in vitro. ${ }^{26}$

Dosis tinggi statin dapat meningkatkan efek samping obat tersebut. FDA membatasi penggunaan dosis tinggi simvastatin $80 \mathrm{mg}$ karena peningkatan risiko terjadinya miopati. Dosis tinggi simvastatin tidak boleh diberikan pada pasien baru yang mengkonsumsi simvastatin. Penggunaan simvastatin direkomendasikan dimulasi pada dosis rendah. Pemberian dosis yang lebih tinggi dapat diperlukan apabila pasien telah mengkonsumsi obat tersebut lebih dari satu tahun. Efek samping penggunaan statin adalah miopati, yang paling serius adalah rhabdomiolisis dan dapat berbahaya bagi ginjal. Rhabdomiolisis terjadi pada 4,9 orang dari 100.000 orang yang mengkonsumsi simvastatin tiap tahun. ${ }^{27}$

Dari uji posteriori Tamhane pada penelitian ini didapatkan bahwa tidak terdapat perbedaan bermakna pada penurunan kadar limfosit simvastatin dosis 0,03 $\mathrm{mg}$ dibandingkan dengan dosis $0,06 \mathrm{mg}$ dan dosis $0,12 \mathrm{mg}$, tetapi terdapat perbedaan bermakna kadar limfosit pada dosis simvastatin $0,06 \mathrm{mg}$ dibandingkan dengan dosis $0,12 \mathrm{mg}$.

Pada pemberian obat seperti simvastatin akan dicari dosis sekecil mungkin yang cukup mampu memberikan efek terapi, sehingga efek samping akibat kelebihan dosis obat dapat dikurangi. Dari penelitian ini dosis $0,03 \mathrm{mg}$ pada mencit yang setara dengan $10 \mathrm{mg}$ sudah mampu menyebabkan penurunan kadar limfosit dan tidak berbeda dengan dosis
0,06 mg tetapi kadar limfosit meningkat kembali pada pemakaian simvastatin dosis $0,12 \mathrm{mg}$ walaupun nilainya jauh dibawah kelompok kontrol. Dosis simvastatin $0,03 \mathrm{mg}$ pada mencit sudah cukup efektif untuk menurunkan jumlah limfosit.

Penelitian ini menunjukkan bahwa simvastatin, suatu HMG-CoA reduktase inhibitor, dapat menurunkan kadar proliferasi limfosit. Hipotesis yang sering berkembang penyebab terjadinya penurunan kadar limfosit disebabkan karena statin menekan induksi dari ekspresi Class II Major Histocompatibility complex (MHC-II) yang diinduced oleh IFN- $\gamma$. Statin bekerja pada level transkripsi dengan cara inhibisi class II transactivator (CIITA) IV promoter. Penurunan ekspresi MHC II berakibat pada inhibisi aktivasi CD 4 limfosit, sehingga mengakibatkan penurunan diferensiasi Th1 dan inhibisi pelepasan sitokin proinflamasi juga menurun. Pada penelitian ini ditemukan bahwa terdapat penurunan kadar limfosit setelah pemberian LPS pada mencit yang diberikan simvastatin.

\section{SIMPULAN}

Simvastatin dosis $0,03 \mathrm{mg}, 0,06 \mathrm{mg}$ dan 0,12 mg menyebabkan kadar proliferasi limfosit pada mencit yang diberi LPS intraperitoneal lebih rendah dibandingkan dengan mencit yang tidak mendapat simvastatin. Terdapat adanya dose effect relationship dari kadar limfosit mencit yang diberi 
lipopolisakarida intraperitoneal setelah pemberian simvastatin pada berbagai dosis. Dosis 0,06mg memiliki efek menekan kadar proliferasi limfosit paling besar.

\section{DAFTAR PUSTAKA}

1. Almog Y, Shefer A, Novack V et al. Prior statin therapy is associated with a decreased rate of severe sepsis. Circulation. 2004; 110: 880-5

2. Almog Y. Statins, inflammation and sepsis. Chest. 2003; 124: 740-3

3. Dellinger RP, Levy MM, Carlet JM et al. Surviving sepsis campaign: International guidelines for management of severe sepsis and septic shock: 2008. Crit Care Med. 2008; 1-33

4. Chiche L, Forel JM, Thomas G et al. The role of natural killer cells in sepsis. Journal of biomedicine and biotechnology. 2011:18 .

5. Karl IE. Pathogenesis of Sepsis and Multi Organ Dysfunction. J Cell Biochem 1992;267:10931-44.

6. Hermawan AG. Sitokin yang berperan dalam SIRS dan Sepsis. SIRS, Sepsis dan Syok Septik (Imunologi, Diagnosis, Penatalaksanaan). Edisi Pertama. Sebelas Maret University Press. 2008; 19-30

7. Gao F,Linhartova L,Johnston A, Thickett DR. Statins and sepsis. Br J Anaesth. 2008; 100: $288-98$

8. Janeway CA, Travers P, Walport M, Shlomchik M. Immunobiology : The immune system in health and disease. Fifth edition. New York; Churchill Livingstone, 2001: 1-34.

9. Greenwood J, Mason JC. Statins and the Vascular Endothelial Inflammatory Response. Trends Immunol. 2007; 28: 88-98

10. Katzung BG. Agents Used in Hyperlipidemia. In Basic and Clinical Pharmacology. 10th Ed. Mc Graw-Hill. New York.2007. ebook

11. Greenwood J, Steinman L, Zamvil SS. Statin
Therapy and Autoimmune Disease: from Protein Prenylation to Immunomodulation. Nat Rev Immunol 2006; 6: 358-70

12. Almog Y, Novack V, Eisinger M, Porath A, Novack L, Gilutz H. The Effect of Statin Therapy on Infection-Related Mortality in Patients with Atherosclerotic Diseases. Crit Care Med 2007; 35: 372-8.

13. Merx MWM, Liehn EAM, Graf JM. Statin Treatment after Onset of Sepsis in a Murine Model Improves Survival. Circulation 2005; 112: 117-24

14. Merx MWM, Liehn EAM, Janssens UM. HMG-CoA Reductase Inhibitor Simvastatin Profoundly Improves Survival in a Murine Model of Sepsis. Circulation 2004; 109: 2560 $-5$

15.Zelvyte I, Dominaitiene R, Crisby M, Janciauskiene S. Modulation of Inflammatory Mediators and PPARgamma and NFkappaB Expression by Pravastatin in Response to Lipoproteins in Human Monocytes in vitro. Pharmacol Res. 2002; 45: 147-154.

16. Yasuda H, Yuen PS, Hu X, Zhou H, Star RA. Simvastatin Improves Sepsis-Induced Mortality and Acute Kidney Injury via Renal Vascular Effects. Kidney Int 2006; 69: 1535-42

17. Arnaud C, Burger F, Steffens S. Statins Reduce Interleukin-6-Induced C-Reactive Protein in Human Hepatocytes: New Evidence for Direct Anti inflammatory Effects of Statins. Arterioscler Thromb Vasc Biol 2005; 25: 1231-6

18. Merx MW, Weber C. Sepsis and the heart. Circulation. 2007; 116:793-802.

19. Anel R, Kumar A. Human endotoxemia and human sepsis: limits to the model. Critical Care 2005, 9:151-152

20. Raetz RH, Whitfield C. Lipopolysaccharide Endotoxins. Annu Rev Biochem 2002; 71: 635-700.

21. Neuhaus O, Strasser-Fuchs S, Fazekas F et al. Statins as immunomodulators comparison with interferon- $\beta 1 \mathrm{~b}$ in MS. Neurology. 2002; 59: 990 - 7

22. Hillyard DZ, Cameron AJM, McDonald KJ et al. Simvastatin inhibits lymphocyte func- 
tion in normal subjects and patients with cardiovascular disease. Atherosclerosis. 2004; 175(2): $305-13$

23. Mach F. Statins as immunomodulatory agents. Circulation. 2004:109:II-15-II-17.

24. McKay A, Leung BP, McInnes IB et al. A novel anti-inflammatory role of simvastatin in a murine model of allergic asthma. The Journal of Immunology. 2004; 172: 2903 - 8

25. Nie C, Yang D, Liu G et al. Statins induce immunosuppressive effect on heterotopic limb allografts in rat through inhibiting $\mathrm{T}$ cell activation and proliferation. European Journal of Pharmacology. 2009; 602 (1): 168 75

26. Hillyard DZ, Cameron AJ, MCIntyre AH et al. Inhibition of proliferation and signaling mechanisms in human lymphocytes by fluvastatin. Clin Exp Pharmacol Physiology. 2002; 29 (28): $673-8$

27. Wratchford P, Ponte CD. High-Dose Simvastatin and Rhabdomyolysis. Am J Health Syst Pharm. 2003;60(7) 3. 